\title{
Environmental and Socioeconomic Indicators for Bioenergy Sustainability as Applied to Eucalyptus
}

\author{
Virginia H. Dale, Matthew H. Langholtz, Beau M. Wesh, and Laurence M. Eaton \\ Oak Ridge National Laboratory, Environmental Sciences Division, Center for BioEnergy Sustainability, Oak Ridge, TN 37831, USA \\ Correspondence should be addressed to Virginia H. Dale; dalevh@ornl.gov
}

Received 9 July 2012; Revised 27 September 2012; Accepted 28 November 2012

Academic Editor: John Stanturf

Copyright ( 2013 Virginia H. Dale et al. This is an open access article distributed under the Creative Commons Attribution License, which permits unrestricted use, distribution, and reproduction in any medium, provided the original work is properly cited.

\begin{abstract}
Eucalyptus is a fast-growing tree native to Australia and could be used to supply biomass for bioenergy and other purposes along the coastal regions of the southeastern United States (USA). At a farmgate price of $\$ 66 \mathrm{dry} \mathrm{Mg}^{-1}$, a potential supply of 27 to 41.3 million dry $\mathrm{Mg} \mathrm{year}^{-1}$ of Eucalyptus could be produced on about 1.75 million ha in the southeastern USA. A proposed suite of indicators provides a practical and consistent way to measure the sustainability of a particular situation where Eucalyptus might be grown as a feedstock for conversion to bioenergy. Applying this indicator suite to Eucalyptus culture in the southeastern USA provides a basis for the practical evaluation of socioeconomic and environmental sustainability in those systems. Sustainability issues associated with using Eucalyptus for bioenergy do not differ greatly from those of other feedstocks, for prior land-use practices are a dominant influence. Particular concerns focus on the potential for invasiveness, water use, and social acceptance. This paper discusses opportunities and constraints of sustainable production of Eucalyptus in the southeastern USA. For example, potential effects on sustainability that can occur in all five stages of the biofuel life cycle are depicted.
\end{abstract}

\section{Introduction}

As society moves forward toward considering energy options other than petroleum-based fuels, bioenergy is an important alternative to evaluate. In addition to developing the ability to provide energy, it is important to identify ways to do so in a sustainable manner. The concept of sustainability refers to activities that support long-term balance in environmental, social, and economic conditions in particular circumstances. Brundtland [1] defined it as the capacity of an activity to operate while maintaining options for future generations. Yet development and use of energy always has some environmental impacts, for example, on water and air quality and biodiversity. The challenge, therefore, is to develop means to address tradeoffs in the costs and benefits in energy choices while considering effects on both environmental and socioeconomic aspects of sustainability. The first step in determining these effects is developing a means to quantify and measure Brundtland's broad definition of sustainability. Building on prior efforts, this paper discusses proposed indicators of sustainability and attempts to apply them to evaluate the potential for using Eucalyptus for sustainable bioenergy in the southeastern United States (USA). However the application of sustainability indicators in this situation is limited by the paucity of pertinent information. Hence, this analysis also suggests key information that needs to be obtained in order to evaluate sustainability of using Eucalyptus for bioenergy in the southeastern USA.

Approaches to bioenergy options should consider a diversity of feedstock options that are suitable in different regions and contexts. Feedstocks being considered for bioenergy in the southeastern USA include forest and agriculture wastes as well as dedicated perennial energy crops such as herbaceous grasses and fast-growing trees [2]. There is no one feedstock type suitable for all places. The appropriate conditions for growing feedstocks in a region depend on prevailing climate and soils, past land-use practices, and existing equipment and experience of the growers. In addition, available forest, agriculture, and other residues are also bioenergy feedstocks.

Eucalyptus, a fast-growing tree native to Australia, is currently being grown in the southeastern USA for mulch and is being considered as a potential feedstock for future bioenergy 
production. The purpose of this paper is to discuss (1) the locations and amounts of feedstock that Eucalyptus could provide in the southeastern USA and (2) how environmental and socioeconomic indicators can be used to evaluate the sustainability of a bioenergy industry based on Eucalyptus. While this paper focuses on sustainability of Eucalyptus for bioenergy in the southeastern USA, we designed it to serve as a template for how sustainability implications of bioenergy crop options can be considered at the regional scale. However difficult challenges remain such as obtaining the data necessary for such quantitative evaluation and determining appropriate and useful methods for collective evaluation of the many components of sustainability.

\section{Short-Rotation Woody Crops and Eucalyptus Potential as a Bioenergy Crop in the Southeastern USA}

Eucalyptus spp. is the world's most widely planted hardwood genus. Its fast, uniform growth, self-pruning behavior, and ability to coppice make it desirable for timber, pulpwood, and bioenergy feedstocks. High yield is an important attribute for any short-rotation woody crop (SRWC), for it improves the economics and reduces the area needed for production. In Brazil, Eucalyptus hybrids such as E. grandis $\times$ E. urophylla produce 22 to 27 dry $\mathrm{Mg} \mathrm{ha}^{-1} \mathrm{yr}^{-1}$ [7]. In Florida E. grandis can achieve more than 34 dry $\mathrm{Mg} \mathrm{ha}^{-1} \mathrm{yr}^{-1}$ [8], rivaling yields of such potential feedstocks as Sacchrum spp. (energy cane) and Pennisetum purpureum (napier grass). Hence there is great interest in Eucalyptus as a bioenergy feedstock.

Estimating the location of where Eucalyptus might be planted to support the bioenergy industry is a prerequisite for considering its effects. Eucalyptus production for bioenergy in the southeastern USA is likely to occur along the southeastern Atlantic and Gulf of Mexico coastal regions of the USA where Eucalyptus's lack of hardiness to frost entails a low to moderate risk (Figure 1) [3]. This area encompasses some places with existing production of Eucalyptus. For example, Eucalyptus grandis has been grown as a commercial crop in Florida primarily for mulchwood for the past five decades [9], largely relying on its ability to sprout prolifically subsequent to coppicing. ArborGen has developed a freezetolerant Eucalyptus, that has a tolerance down to $-8.9^{\circ} \mathrm{C}$ while maintaining high productivity [7]. It is not certain how climate changes and associated changes in hardiness zones may affect the potential areas where Eucalyptus might grow. In any case, Eucalyptus will most likely be grown along the coastal areas of the southeastern USA where both frost hardiness and salt tolerance may be an issue.

We provide estimates of the potential supplies of Eucalyptus for bioenergy by utilizing projections generated from the Billion-Ton Update, which estimated the forest and agricultural resource potential for the expansion of bioenergy and bioproducts industries [2]. Estimates of biomass supplies were produced for a range of prices, and the amounts and locations were specified at the county/parish level with projections from 2012 to 2030 . Feedstocks include all major primary and secondary forest and agricultural residues,

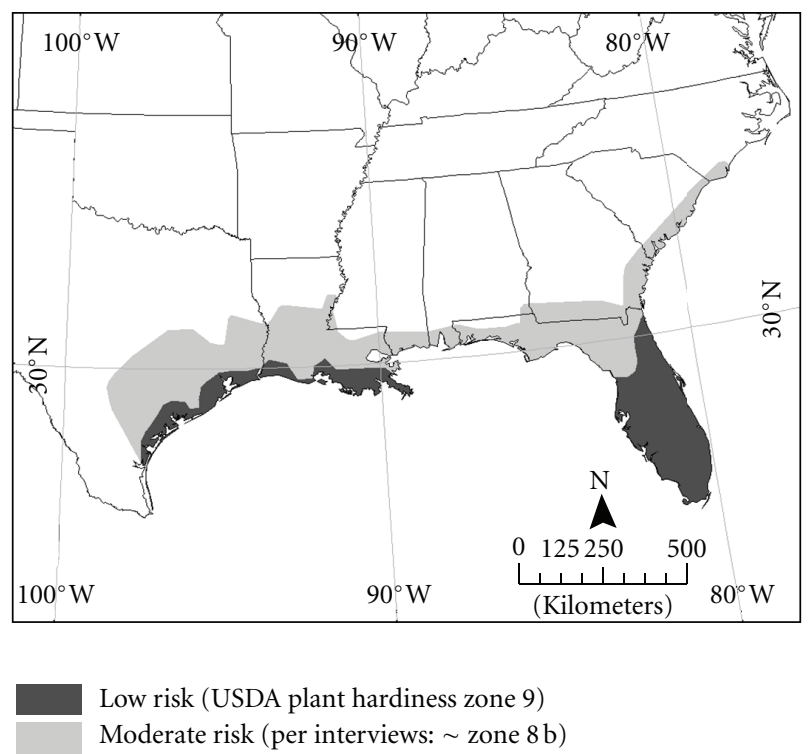

Figure 1: Map of locations for potential feedstock locations for Eucalyptus in the United States that could be used for bioenergy (as estimated by Kline and Coleman [3] based on the USDA Plant Hardiness Zones [6] and interviews with experts).

major waste feedstocks, and energy crops grown specifically for bioenergy, including SRWCs. The models in the BillionTon Update incorporate yields and production budgets that represent commercial-scale production of various SRWC species, including willow (Salix spp.), loblolly pine (Pinus taeda), poplar (Populus spp.), and, of interest to this paper, Eucalyptus.

Projections of biomass production were made for the Billion-Ton Update using supply/cost curves generated by POLYSYS [10, 11] for each major feedstock group for a baseline and a high-yield case. The baseline case assumes a continuation of the USA Department of Agriculture's 10year forecast of yields for major food and forage crops to 2018 and then extrapolates it to 2030. The high-yield scenario assumes increased yields and higher adoption of no-till cultivation for traditional crops. All energy crops are assumed to have annual yield increase of $1 \%$ for the baseline case, and three levels of increase (2\%, 3\%, and $4 \%$ ) were considered for the high-yield scenario. In addition, the POLYSYS model assumes that, in order for energy crops to be grown in a county, the crops must provide a higher net return than the commodity crops or pastures that they displace, and there can only be limited impacts on food, feed, exports, and fiber production. Furthermore, pasture can only convert to energy crops if the displaced forage is made up through intensification. Energy crops are not allowed on irrigated cropland or pasture. Best Management Practices (BMPs) are assumed to be used for establishment, cultivation, maintenance, and harvesting of energy crops. Additionally, energy crops are allowed to compete against each other for land on a per-acre net return basis. Other assumptions of the POLYSYS analysis used by the Billion-Ton Update are 


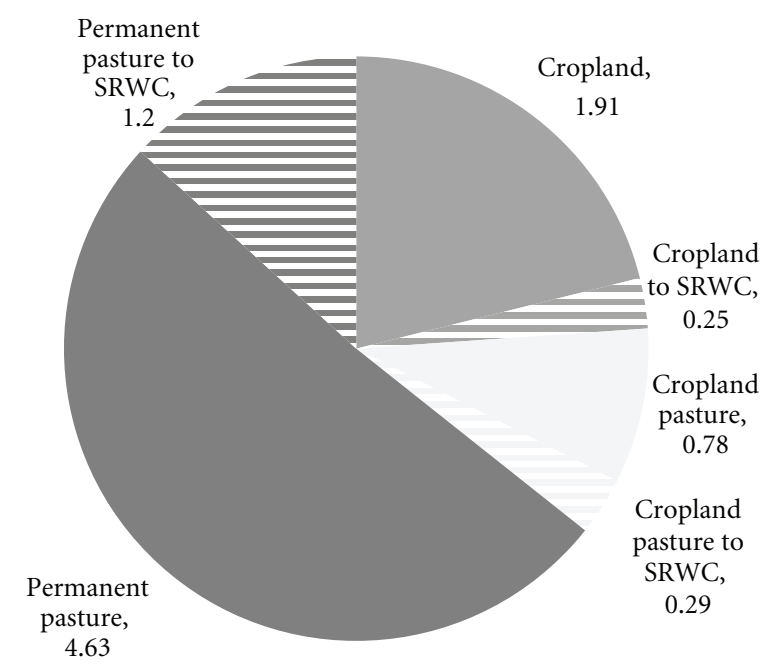

FIGURE 2: Current allocation of cropland, cropland pasture, and permanent pasture to SRWC within the potential geographic range of Eucalyptus (Billion-Ton Update Base Case Scenario assuming $\$ 66 / \mathrm{Mg}^{-1}$ farmgate price, results for year 2030).

detailed in the full report (see Appendix B of the report for general modeling assumptions) [2].

To quantify an upper limit of sustainable production of Eucalyptus in response to a bioenergy market as constrained by the POLYSYS assumptions summarized above, we disaggregated the SRWC production estimates from the BillionTon Update for the 192 counties in the Eucalyptus production ranges shown in Figure 2. Those 192 counties were identified as having centroids within the low- and moderate-risk Eucalyptus ranges shown in Figure 1. County-level POLYSYS results for SRWC production in these 192 counties were used to estimate potential Eucalyptus production (yield and land area) in the USA. POLYSYS simulates SRWCs in this range as any tree species that is managed as single-stem for eight-year rotations and yielding a mean annual increment of about 13 dry $\mathrm{Mg} \mathrm{ha}^{-1} \mathrm{yr}^{-1}$, with yields projected to increase with future improvements. Actual Eucalyptus production practices would deviate from these assumptions, for some of the simulated SRWC production will be met with pine, poplars, or other species.

We estimate a supply potential in year 2030 of 27 to 41 million dry $\mathrm{Mg}_{\mathrm{gear}}{ }^{-1}$ of Eucalyptus production potential in the Southeast by assuming all SRWC production is realized by Eucalyptus within the baseline and a high-yield case estimated by the Billion-Ton Update and shown in Figure 2. This calculation derives from simulating a farmgate price of $\$ 66$ dry $\mathrm{Mg}^{-1}\left(\$ 60\right.$ dry ton $\left.^{-1}\right)$ under the baseline and highyield (4\% yield increase) scenarios. Under these assumptions, the Billion-Ton Update estimates that 1.0 to 1.5 billion dry $\mathrm{Mg} \mathrm{year}^{-1}$ of biomass are available from all sources in the conterminous USA by 2030 [2]. These projections include 114 to 285 million dry Mg year ${ }^{-1}$ of SRWC, of which 27 to 41 million dry $\mathrm{Mg}_{\mathrm{year}}{ }^{-1}$ are produced in the 192 counties identified above in 2030 .
To illustrate the scale of potential landscape change that might be attributable to future Eucalyptus production, land use and conversion from this same simulation is shown in Table 1 and Figure 2. Assuming a farmgate price of $\$ 66$ dry $\mathrm{Mg}^{-1}$, these model results suggest that up to 0.25 , 0.29 , and 1.20 million hectares of cropland, cropland pasture, and permanent pasture within the geographic range of Eucalyptus production could be converted to SRWCs by the year 2030. This amount represents about $19 \%$ of the agricultural land and $4.5 \%$ of total land in these 192 counties.

POLYSYS is constrained to only allow SRWC production on non-forested land but also projects feedstock supplies to 2030 from logging residues, thinnings, and pulpwood from forest land. Depending on policy, economics, and landowner values, forestland might also be brought into Eucalyptus production. For example, this same POLYSYS simulation produces $200,900 \mathrm{Mg}$ of softwood pulpwood in 2030 from the 192 selected counties. Assuming a mean annual increment of $11 \mathrm{Mg} \mathrm{ha}^{-1} \mathrm{yr}^{-1}$, this material could be drawn from about 18 thousand hectares of forestland, some of which could be converted from pine to Eucalyptus or other SRWC plantations. Hence the potential aggregate change of the landscape of about 1.8 million ha warrants critical evaluation of possible effects.

\section{Assessing Sustainability of the Eucalyptus Biofuel Supply Chain via Indicators}

To assess sustainability, means of quantifying it have to be specified. Brundtland's broad definition of sustainability is useful but is nonspecific. Therefore, many groups have been working toward establishing a set of indicators that can be used to quantify bioenergy sustainability (e.g., the Roundtable on Sustainable Biofuels [12], Global Bioenergy Partnership [13], and Council on Sustainable Biomass Production [14]). However, implementation is hampered when indicators are too numerous, too costly, and too broad [15] as is the case for current efforts.

Thus, our team of researchers at Oak Ridge National Laboratory considered bioenergy sustainability indicators proposed by many groups and selected a small set of measureable indicators of bioenergy sustainability using the criteria of being practical, sensitive to stresses, unambiguous, anticipatory, predictive, calibrated with known variability, and sufficient when considered collectively [16]. These conditions are also prerequisites for energy security [17] as well as other aspects of sustainability. Furthermore, the selected indicators are less cumbersome than those proposed by other groups because we assume they only apply in situations that have basic legal, regulatory, and enforcement services and transparent, stable, and legitimate governance. This final assumption is critical, for it avoids situations where bioenergy has been called on to resolve major development challenges such as lack of land tenure or government corruption.

We hypothesize that the selected suite of 35 environmental and socioeconomic indicators provides a practical and consistent way to assess the sustainability of a particular situation where a feedstock might be grown and converted 
TABLE 1: Area of cropland, cropland pasture, and permanent pasture (1) in the USA lower forty-eight states, (2) in Eucalyptus ranges in the Southeast, (3) potentially converted to Eucalyptus in a Base Case Scenario, and (4) potentially converted to Eucalyptus in a High-yield Scenario.

\begin{tabular}{lccc}
\hline & Cropland & $\begin{array}{c}\text { Cropland Pasture } \\
\text { (million hectares) }\end{array}$ & $\begin{array}{c}\text { Permanent Pasture } \\
\text { (1) USA (lower 48 states) total }\end{array}$ \\
(2) Total in Eucalyptus range $^{\mathrm{b}}$ & 125.82 & 13.15 & 155.59 \\
(3) Converted from (2) to SRWC, Base Case $^{\mathrm{c}}$ & 2.17 & 1.07 & 5.83 \\
(3) Converted from (2) to SRWC, High-yield $^{\mathrm{d}}$ & 0.25 & 0.29 & 1.20 \\
\hline
\end{tabular}

Census of Agriculture, 2007.

${ }^{\mathrm{b}}$ Includes counties with centroids contained by both low- and moderate-risk Eucalyptus ranges from Kline and Coleman [3] shown in Figure 1.

${ }^{\mathrm{c}}$ Areas in (2) above that are converted to SRWC in the Billion-Ton Update (DOE 2011) [2], assuming $\$ 66 \mathrm{dry} \mathrm{Mg}^{-1}$ farmgate price, Base Case Scenario.

${ }^{\mathrm{d}}$ Areas in (2) above that are converted to SRWC in the Billion-Ton Update (DOE 2011) [2], assuming $\$ 66 \mathrm{dry} \mathrm{Mg}^{-1}$ farmgate price, High-Yield Scenario.

TABLE 2: List of recommended environmental indicators for bioenergy sustainability (derived from [4]).

\begin{tabular}{|c|c|c|}
\hline Category & Indicator & Units \\
\hline \multirow{4}{*}{ Soil quality } & (1) Total organic carbon (TOC) & $\mathrm{Mg} / \mathrm{ha}$ \\
\hline & (2) Total nitrogen $(\mathrm{N})$ & $\mathrm{Mg} / \mathrm{ha}$ \\
\hline & (3) Extractable phosphorus (P) & $\mathrm{Mg} / \mathrm{ha}$ \\
\hline & (4) Bulk density & $\mathrm{g} / \mathrm{cm}^{3}$ \\
\hline \multirow{7}{*}{$\begin{array}{l}\text { Water quality } \\
\text { and quantity }\end{array}$} & (5) Nitrate concentration in streams (and export) & concentration: $\mathrm{mg} / \mathrm{L}$; export: $\mathrm{kg} / \mathrm{ha} / \mathrm{yr}$ \\
\hline & (6) Total phosphorus (P) concentration in streams (and export) & concentration: $\mathrm{mg} / \mathrm{L}$; export: $\mathrm{kg} / \mathrm{ha} / \mathrm{yr}$ \\
\hline & (7) Suspended sediment concentration in streams (and export) & concentration: $\mathrm{mg} / \mathrm{L}$; export: $\mathrm{kg} / \mathrm{ha} / \mathrm{yr}$ \\
\hline & (8) Herbicide concentration in streams (and export) & concentration: $\mathrm{mg} / \mathrm{L}$; export: $\mathrm{kg} / \mathrm{ha} / \mathrm{yr}$ \\
\hline & (9) Peak storm flow & $\mathrm{L} / \mathrm{s}$ \\
\hline & (10) Minimum base flow & $\mathrm{L} / \mathrm{s}$ \\
\hline & (11) Consumptive water use (incorporates base flow) & $\begin{array}{l}\text { feedstock production: } \mathrm{m}^{3} / \text { ha/day; } \\
\text { biorefinery: } \mathrm{m}^{3} / \text { day }\end{array}$ \\
\hline $\begin{array}{l}\text { Greenhouse } \\
\text { gases }\end{array}$ & (12) $\mathrm{CO}_{2}$ equivalent emissions $\left(\mathrm{CO}_{2}\right.$ and $\left.\mathrm{N}_{2} \mathrm{O}\right)$ & $\mathrm{kgC}_{\mathrm{eq}} / \mathrm{GJ}$ \\
\hline \multirow{2}{*}{ Biodiversity } & (13) Presence of taxa of special concern & Presence \\
\hline & (14) Habitat area of taxa of special concern & $\mathrm{Ha}$ \\
\hline \multirow{4}{*}{ Air quality } & (15) Tropospheric ozone & $\mathrm{Ppb}$ \\
\hline & (16) Carbon monoxide & Ppm \\
\hline & (17) Total particulate matter less than $2.5 \mu \mathrm{m}$ diameter $\left(\mathrm{PM}_{2.5}\right)$ & $\mu \mathrm{g} / \mathrm{m}^{3}$ \\
\hline & (18) Total particulate matter less than $10 \mu \mathrm{m}$ diameter $\left(\mathrm{PM}_{10}\right)$ & $\mu \mathrm{g} / \mathrm{m}^{3}$ \\
\hline Productivity & (19) Aboveground net primary productivity (ANPP)/Yield & $\mathrm{gC} / \mathrm{m}^{2} /$ year \\
\hline
\end{tabular}

to bioenergy. The 19 environmental indicators of bioenergy sustainability fall into the categories of soil quality, water quality and quantity, greenhouse gases, biodiversity, air quality, and productivity (Table 2) [4]. Socioeconomic aspects of bioenergy sustainability are defined by 16 indicators that fall into the categories of social wellbeing, energy security, trade, profitability, resource conservation, and social acceptability (Table 3) [5]. These indicators constitute a way to assess the capacity of bioenergy systems to advance toward the goal of sustainability. Here we consider how these 35 indicators can be applied to the use of Eucalyptus to produce bioenergy in the southeastern USA.

Indicators of bioenergy sustainability can be applied conceptually to a region, but actual application should be context specific [18]. For example, sustainability of Eucalyptus depends on a variety of factors, such as prevailing environmental conditions, ongoing management, previous land practices, and intended use of the product. While we discuss how these indicators might be applied to Eucalyptus deployment in the southeastern USA for bioenergy, actual evaluation of the sustainability of Eucalyptus depends on the specific situation and management, and much of that information is not yet known. Therefore, when appropriate and possible, we rely on information from other locations and uses of Eucalyptus other than for bioenergy.

To illustrate their application, we discuss how potential effects on sustainability of using Eucalyptus for bioenergy occur in all five stages of the biofuel life cycle (Table 4): feedstock production, feedstock logistics, conversion to biofuel, biofuel logistics, and biofuel end uses. Each is discussed below. All feedstock types have effects (e.g., on greenhouse gas emissions, air quality, profitability, social well being, trade, energy security, resource conservation and social acceptability) that are distributed throughout the supply 
TABLE 3: List of recommended socioeconomic indicators for bioenergy sustainability (derived from Dale et al. (2013) [5]).

\begin{tabular}{|c|c|c|}
\hline Category & Indicator & Units \\
\hline \multirow{4}{*}{ Social well being } & Employment & Number of full time equivalent (FTE) jobs ${ }^{1}$ \\
\hline & Household income & Dollars per day \\
\hline & Work days lost due to injury & Average number of work days lost per worker per year \\
\hline & Food security & Percent change in food price volatility \\
\hline \multirow{2}{*}{ Energy security } & Energy security premium & Dollars/gallon biofuel \\
\hline & Fuel supply volatility & $\begin{array}{l}\text { Standard deviation of monthly percentage price changes over one } \\
\text { year }\end{array}$ \\
\hline \multirow{2}{*}{ External trade } & Terms of trade & Ratio (price of exports/price of imports) \\
\hline & Trade volume & Dollars (net exports or balance of payments) \\
\hline \multirow[t]{2}{*}{ Profitability } & $\begin{array}{l}\text { Return on investment } \\
(\mathrm{ROI})^{1}\end{array}$ & Percent (net investment/initial investment) \\
\hline & Net present value $(\mathrm{NPV})^{2,3}$ & Dollars (present value of benefits minus present value of costs) \\
\hline \multirow{2}{*}{$\begin{array}{l}\text { Resource } \\
\text { conservation }\end{array}$} & $\begin{array}{l}\text { Depletion of non-renewable } \\
\text { energy resources }\end{array}$ & Amount of petroleum extracted per year (MT) \\
\hline & $\begin{array}{l}\text { Fossil Energy Return on } \\
\text { Investment (fossil EROI) }\end{array}$ & $\begin{array}{l}\text { Ratio of amount of fossil energy inputs to amount of useful energy } \\
\text { output (MJ) (adjusted for energy quality) }\end{array}$ \\
\hline \multirow{4}{*}{ Social acceptability } & Public opinion & Percent favorable opinion \\
\hline & Transparency & $\begin{array}{l}\text { Percent of indicators for which timely and relevant performance } \\
\text { data are reported }\end{array}$ \\
\hline & $\begin{array}{l}\text { Effective stakeholder } \\
\text { participation }\end{array}$ & $\begin{array}{l}\text { Percent of documented responses to stakeholder concerns and } \\
\text { suggestions reported on an annual basis }\end{array}$ \\
\hline & Risk of catastrophe ${ }^{4}$ & Annual probability of catastrophic event \\
\hline
\end{tabular}

\footnotetext{
FTE employment includes net new jobs created, plus jobs maintained that otherwise would have been lost, as a result of the system being assessed.

${ }^{2}$ Conventional economic models can address long-term sustainability issues by extending the planning horizon, projecting as an infinite geometric series, or calculating with a low discount rate.

${ }^{3}$ Can be expanded to include non-market externalities (e.g., water quality, GHG emissions).

${ }^{4}$ A catastrophic event can be defined as an event or accident that has more than 10 human fatalities, affects an area greater than 1000 ha, or leads to extinction or extirpation of a species.

${ }^{5}$ For example this measure could be the percent of all social, economic and environmental indicators identified via stakeholder consultation or the percent of the 35 indicators listed here and in McBride et al. [4] for which relevant baseline, target, and performance data are reported and made available to the public on a timely basis (at least annually).
}

chain; however much more is known about the feedstock production stage for Eucalyptus.

3.1. Feedstock Production. Feedstock production builds from the current condition of the land, soil, and water resources and encompasses propagation, site preparation, establishment, and management. Sustainability effects of bioenergy that are specific to Eucalyptus and other SRWC are largely concentrated in the feedstock production stage of the life cycle (Table 4). As with any dedicated biomass plantation, Eucalyptus plantations can affect all six categories of environmental indicators (soil quality, water quality and quantity, greenhouse gases, biodiversity, air quality, and productivity), and the effects are specific to each location, prior conditions, and management practice.

Resource conditions prior to establishment of plantations have significant implications on effects of these attributes. These conditions include the soil, water, and air quality, as well as biodiversity and habitat circumstances of the area prior to the establishment of the crop. The sign and degree of effects are different for each situation. The effects can be negative where clearing natural forests compromises biodiversity or soil conditions and depend on the spatial scale being considered [19]. Carbon sequestration of Eucalyptus plantations on prior pasture lands is influenced by precipitation patterns and intervals between harvests [20]. The effects can be positive in cases where plantations replace little or poorly managed vegetation, or negative if the plantations are poorly managed and replace well-established and productive stands. For example, when established on former pasture land in southern Europe, E. nitens and E. globulus enhance carbon sequestration in both biomass and soil [21]. And studies of E. nitens in Australia confirm that management via thinning, pruning, and nitrogen fertilization has interactive effects on above-ground biomass and biomass partitioning among crown, bole, and roots [22]. As another example, Eucalyptus has been demonstrated to provide beneficial impacts on soil quality, water quality and quantity, greenhouse gases, and biodiversity when Eucalyptus plantations are established for purposes of mine land reclamation or phytoremediation (e.g., [23-29]) and could be used on other degraded land. As with any other bioenergy crop, appropriate lands and management practices must be used if sustainability is to be achieved.

Water use by Eucalyptus grown for bioenergy is a concern where water is scarce, as is the case during droughts and 
TABLE 4: Categories of sustainability indicators that experience environmental or socioeconomic effects within the Eucalyptus-to-biofuel supply chain. Major effects for Eucalyptus and other fast-growing non-native crops are depicted by $*$, and additional effects exhibited by all feedstocks are depicted by + . A blank means there is no effect in that category.

\begin{tabular}{|c|c|c|c|c|c|c|c|c|c|c|c|c|c|}
\hline Categories & f indicators & & & nme & $1 \mathrm{Eff}$ & & & & & ecor & ic Ef & & \\
\hline $\begin{array}{l}\text { Steps in biofuel } \\
\text { supply chain }\end{array}$ & $\begin{array}{l}\text { Components of } \\
\text { each biofuel } \\
\text { supply chain } \\
\text { step }\end{array}$ & 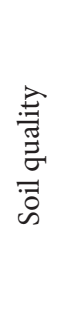 & 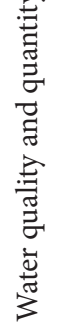 & 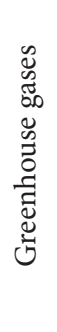 & 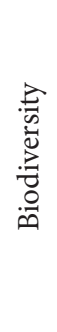 & 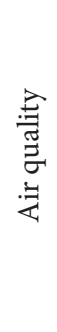 & 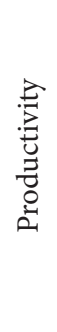 & 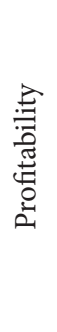 & 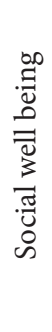 & 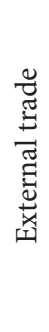 & 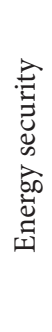 & 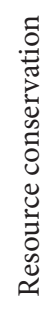 & 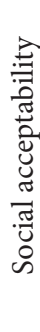 \\
\hline Feedstock & $\begin{array}{l}\text { Resource } \\
\text { Conditions }\end{array}$ & * & * & * & * & * & * & + & + & & & + & * \\
\hline Production & Feedstock Type & $*$ & * & $*$ & $*$ & $*$ & $*$ & $*$ & + & + & + & + & * \\
\hline & Management & $*$ & * & * & * & * & * & + & + & & & + & * \\
\hline & $\begin{array}{l}\text { Harvesting \& } \\
\text { Collection }\end{array}$ & + & * & + & + & + & + & * & + & & & & + \\
\hline $\begin{array}{l}\text { Feedstock } \\
\text { Logistics }\end{array}$ & Processing & & & + & & + & & + & + & & & & + \\
\hline & Storage & & & + & & + & & + & + & & + & & + \\
\hline & Transport & & & + & + & + & & + & + & + & & + & + \\
\hline Conversion to & $\begin{array}{l}\text { Conversion } \\
\text { Process }\end{array}$ & & + & + & & + & & + & + & + & + & + & + \\
\hline Biofuel & Fuel Type & & & + & & & & + & + & + & + & + & \\
\hline & Coproducts & & + & + & & + & & + & + & + & + & + & \\
\hline Biofuel Logistics & Transport & & & + & & + & & + & + & + & & & + \\
\hline & Storage & & & + & & + & & + & + & + & + & & + \\
\hline $\begin{array}{l}\text { Biofuel End } \\
\text { Uses }\end{array}$ & $\begin{array}{l}\text { Engine Type } \\
\text { and Efficiency }\end{array}$ & & & + & & + & & + & + & + & + & + & + \\
\hline & $\begin{array}{l}\text { Blend } \\
\text { Conditions }\end{array}$ & & & + & & + & & + & + & + & + & + & + \\
\hline
\end{tabular}

for selected areas of the southeastern USA, including parts of the 192 countries where Eucalyptus might be grown. The water scarcity issue is localized and relates more to population growth and demand than to inherent supply limits. Of most concern is groundwater recharge due to deep rooting in areas where the primary drinking water source is groundwater (as in peninsular Florida). As a fast-growing tree, Eucalyptus can use significant amounts of water. This trait may be a concern in areas where groundwater is scarce or may be an asset in applications such as phytoremediation or reclaiming saturated clay settling areas of mined lands [24]. The main question of water use is how tradeoffs in allocation are addressed. Once established, Eucalyptus can tolerate drought and water scarcity. For example, E. occidentalis was able to produce 22 tons/ha in the dry land Mediterranean climate of southwestern Australia [30]. Eucalypts are able to make use of soil water to depths of 8 to $10 \mathrm{~m}$ within 7 years of planting and are able to penetrate clay subsoils [30]. As with other categories of indicators, the interpretation of the values of water quality and quantity indicators is specific to each situation.
Similar to any agricultural or forest land use, mismanagement can result in negative environmental impacts, while appropriate management can enhance or at least maintain environmental quality. The question then becomes, "what are appropriate management practices for Eucalyptus in the southeastern USA?" For example, management practices of Eucalyptus plantations can serve to control soil erosion, with implications for soil and water quality, as well as yield. On many sites in the southeastern USA that are available for planting Eucalpytus, both competing vegetation and low fertility will need to be addressed.

Expansive monocultures managed with stringent control of competing vegetation are likely to reduce biodiversity. Conversely, a mosaic of Eucalyptus stands interspersed on the landscape that includes native vegetation and a diversity of stand structures may have less impact on biodiversity. Preplantation land-use conditions also have implications for biodiversity. For example, higher diversity can occur in pine plantations established on cutover forest land than planted on former agricultural land [31]. Hence, establishing Eucalyptus plantations on land previously cleared for rowcrops or 
pasture in the southeastern USA should be designed to not jeopardize existing biodiversity. Maintaining land in forest or increasing forest area can promote biodiversity via habitat provision services of forests and forest edges.

Areas with high native biodiversity should be excluded from plantation development. In the southeastern USA, high-diversity forest lands are often in federal ownership [32] and are excluded from providing bioenergy feedstocks by the Renewable Fuel Standard [33].

Based on concern about the invasiveness of Eucalyptus because it is a foreign plant to the USA, The Nature Conservancy evaluated it using the Australian Weed Risk Assessment system [34]. Some Eucalyptus species are considered by Florida to be naturalized in disturbed areas and not invasive [35]. Using a check list to evaluate invasiveness, $E$. amplifolia requires further evaluation, but E. camaldulensis and E. grandis are considered invasive [36]. Even in Brazil, where the amount of $E$. grandis plantations are the largest (4.2 $\mathrm{m}$ ha in 2010), E. grandis is not considered invasive for several reasons. The species has very few small seeds within a fire-protective capsule. These capsules help the seeds grow after a fire but prevent them from growing otherwise, for the seed must be on exposed soil to germinate, with survival requiring no surrounding vegetation and full sunlight [6]. These seeds also do not have any characteristics that facilitate dispersal by wind, water, or other means. Hence tree height and the wind conditions are the main factors influencing how far the seeds will travel, and seeds typically fall within a distance of 1.3 times the height of the tree [37]. Furthermore, in order to reduce invasiveness, ArborGen has successfully engineered a Eucalyptus hybrid that does not produce pollen [30]. Introduction of Eucalyptus species into new areas and large-scale plantations requires careful evaluation of their potential for invasiveness [34].

Furthermore, salt-affected soil usually does not support high productivity due to the degradation of the soil. To increase both soil quality and profits, salt-tolerant species such as E. camaldulensis can be grown and harvested on salt-affected soils [36]. E. occidentalis was able to produce 31 tons/ha on salinized soils in southwestern Australia that had previously been abandoned by agriculture [36].

Eucalyptus plantations can also affect all aspects of the socioeconomic components of sustainability: social wellbeing, energy security, trade, profitability, resource conservation, and social acceptability, as does any bioenergy crop. These effects can be positive if the bioenergy system is well managed and located in a place where benefits can accrue. For example, a refinery could be located where rural jobs are in decline, and the establishment of a new industry based on Eucalyptus could revitalize the community while providing a new energy source that might be competitive with fossil fuels. The biggest difference in social acceptability from most other SRWC being proposed for bioenergy in the southeastern USA is that Eucalyptus is not a native species and has high water demands and potential for invasiveness. Use of Eucalyptus has been initially challenged in many places where it is planted but is not native. However, as one example of the turnaround in its public acceptance, expansion of Eucalyptus forestry in Ethiopia resulted in $96 \%$ of growers and $90 \%$ of the district experts supporting that expansion largely for economic reasons and despite environmental concerns [38]. In the USA outside of Florida, there are no state or federal restrictions on planting non-native Eucalyptus, and Florida's restriction is based on invasiveness, not on non-native status. Furthermore, the frost-tolerant hybrid mentioned earlier is a genetically modified organism, which is regulated under federal laws.

As with other forest practices, the use of Eucalyptus for bioenergy provides an opportunity to retain land in forest versus succumbing to other land pressures such as development or urban expansion. The demand for bioenergy and value of the Eucalyptus for that purpose as compared to other activities on the land determine where and how Eucalyptusbased bioenergy will occur. Retaining land in productive forestry could also provide rural socioeconomic benefits such as jobs and profit from the land. While much focus now for bioenergy in the southeastern USA is on perennial grasses, cost projections for Eucalyptus-delivered feedstock may be more economical in some areas. For example, the estimated lowest cost based on simulations of switchgrass is $\$ 67 \mathrm{Mg}^{-1}$, and for Eucalyptus is $\$ 55 \mathrm{Mg}^{-1}$ for the southeastern USA [39].

Currently 9.6 percent of the land in seven Gulf South states where Eucalyptus might grow is in plantation forests [37]. With the forest industry downturn in the southeastern USA, both jobs and forest land are being lost [40, 41]. At the same time, more land is being developed for urban and suburban use, and bioenergy crops, such as Eucalyptus, may offer an opportunity to counteract these trends [42]. To this end, some developments are incorporating a landscape design that includes both forests and houses within the overall planning. For example, a housing development in the coastal region near Ravenal, South Carolina, allocates a portion of the total planned area to forestry where several Eucalyptus spp. are being grown in test trials.

3.2. Feedstock Logistics. Feedstock logistics include the harvesting, processing, storage and transport of the feedstock to the refinery. Of particular environmental concern in Eucalyptus feedstock logistics is effects on water quality and quantity during harvest and on biodiversity during transport. Biofuel cost is highly sensitive to the delivered cost of the Eucalyptus feedstock, which can constitute $35-50 \%$ of the total cost of ethanol production $[43,44]$.

3.3. Conversion to Biofuel, Biofuel Logistics, and Biofuel End Uses. Conversion is the process of changing the feedstock into biofuel and depends on the fuel type selected and any coproducts created. Sometimes the coproducts have more value than the fuel produced. Biofuel logistics is the step of moving fuel (often by truck, rail, or barge) to the end users and storing it. End use involves the engine type in which the fuel is used as well as how much of the biofuel is blended with other fuels. For example, second-generation bioethanol can be acquired from Eucalyptus globulus if refined by specialized autohydrolysis processing, which breaks down the lignocellulose into soluble fragments, followed by Simultaneous Saccharification and Fermentation (SSF) processing, which 
is the fermentation process [45]. However, because there are no feedstock conversion processes to date that use Eucalyptus, there is limited information on how Eucalyptus might differ from other feedstocks in its effects on the last three steps of the life cycle: conversion to biofuel, biofuel logistics, or biofuel end use.

\section{Conclusion, Opportunities, and Constraints for Eucalyptus-Based Bioenergy}

This paper discusses a suite of sustainability indicators that can be applied to Eucalyptus-based bioenergy production in the southeastern USA. While this bioenergy production system has the potential to be environmentally, economically, and socially sustainable, context-specific information is needed before these indicators can be applied to determine conditions under which a system is sustainable. For Eucalyptus growing in the southeastern USA, key concerns and hence critical data needs revolve around potential for invasiveness, water use and social acceptability. Sustainability indicators should be applied as specific projects are deployed.

There are several opportunities provided by using Eucalyptus and other SRWC as feedstocks in the southeastern USA. Most importantly they could provide a new source of bioenergy and associated social and environmental benefits. They may provide a means to retain or expand the area of land in a forest land use, versus having them become developed, and thereby improve biodiversity conditions and water quantity and quality. Eucalyptus and other SRWC plantations may also provide rural jobs.

However, constraints exist to the full deployment of Eucalyptus-based bioenergy in the southeastern USA. Current environmental, sociopolitical, economic, and conditions may limit the places where Eucalyptus might be planted. These limits include pressures for land development, the value of wood and its products, and soils conditions that result from past land use. Furthermore, not all requisite information is currently available at the temporal and spatial scales of resolution at which it is needed to estimate the potential for a successful bioenergy industry based on Eucalyptus or to validate this approach. Therefore, we encourage the collection of data on the indicators in Tables 2 and 3 so that a quantitative evaluation can be made. Necessary information includes current environmental and socioeconomic conditions as well as factors affecting energy choices and their impacts. Another constraint is lack of information on the best management techniques for establishing and growing Eucalyptus in the southeastern USA. The processes for converting Eucalyptus to bioenergy are in their infancy and require development as well. There is a need to develop the industry for producing and converting Eucalyptus to bioenergy. As the bioenergy system based on Eucalyptus is deployed, it will be necessary to identify and address public perceptions and risks. For example, there is widespread concern that Eucalyptus is an invasive species. Finally, genomes of Eucalyptus need to be developed that can deal with environmental stresses that occur in the southeastern USA (such as those that are resistant to frost).
Once (and if) these constraints are surmounted, the benefits of a Eucalyptus-based bioenergy system can possibly be achieved. The forest industry is well positioned to tackle these constraints to feedstock provision using Eucalyptus. Brazil has much experience in growing eucalypts where they constitute about $90 \%$ of the forest plantations. However, it is not clear how much of that knowledge and technology can be transferred to the southeastern USA. The deployment of the bioenergy industry is still in development, and it is unknown how much Eucalyptus will differ from the conversion of other feedstocks. This analysis demonstrates that the sustainability issues associated with using Eucalyptus for bioenergy do not differ greatly from those of other feedstocks. In all cases, it is the specifics of how the industry is developed and deployed that determine the effects on sustainability of current systems.

\section{Acknowledgments}

Maggie Davis provided helpful comments on an earlier version of this paper. John Stanturf and three anonymous reviewers also provided useful suggestions. This research was supported by the USA Department of Energy (DOE) under the Biomass Technologies Office. Oak Ridge National Laboratory is managed by UT-Battelle, LLC, for DOE under Contract DE-AC05-00OR22725.

\section{References}

[1] G. H. Brundtland, Ed., Our Common Future: The World Commission on Environment and Development, Oxford University, Oxford, UK, 1987.

[2] United States Department of Energy, U.S. Billion-Ton Update: Biomass Supply for a Bioenergy and Bioproducts Industry, Oak Ridge National Laboratory, Oak Ridge, Tenn, USA, 2011.

[3] K. L. Kline and M. D. Coleman, "Woody energy crops in the southeastern United States: two centuries of practitioner experience," Biomass and Bioenergy, vol. 34, no. 12, pp. 1655-1666, 2010.

[4] A. C. McBride, V. H. Dale, L. M. Baskaran et al., "Indicators to support environmental sustainability of bioenergy systems," Ecological Indicators, vol. 11, no. 5, pp. 1277-1289, 2011.

[5] V. H. Dale, R. A. Efroymson, K. L. Kline et al., "Indicators for assessing socioeconomic sustainability of bioenergy systems: a short list of practical measures," Ecological Indicators, vol. 26, pp. 87-102, 2013.

[6] United States National Arboretum, USDA Plant Hardiness Zone Map, Based on USDA Miscellaneous, US Department of Agriculture, Washington, DC, USA, 2003, http://www.usna .usda.gov/Hardzone/.

[7] M. Hinchee, W. Rottmann, L. Mullinax et al., "Short-rotation woody crops for bioenergy and biofuels applications," In Vitro Cellular and Developmental Biology, vol. 45, no. 6, pp. 619-629, 2009.

[8] J. A. Stricker, D. L. Rockwood, S. A. Segrest, G. R. Alker, G. M. Prine, and D. R. Carter, "Short Rotation Woody Crops for Florida, University of Florida," http://www.treepower.org/ papers/strickerny.doc, 2000.

[9] D. L. Rockwood, "History and status of Eucalyptus improvement in Florida," International Journal of Foresty Research, vol. 2012, Article ID 607879, 10 pages, 2012. 
[10] D. G. D. Ugarte and R. E. Ray, "Biomass and bioenergy applications of the POLYSYS modeling framework," Biomass and Bioenergy, vol. 18, pp. 291-308, 2000.

[11] M. Langholtz, R. Graham, L. Eaton, R. Perlack, C. Hellwinkel, and D. G. D. Ugarte, "Price projections of feedstocks for biofuels and biopower in the U.S.," Energy Policy, vol. 41, pp. 484-493, 2012.

[12] "Roundtable on Sustainable Biofuels (RSB). Roundtable on Sustainable Biofuels-Indicators of Compliance for the RSB Principles \& Criteria. École Polytechnique Fédérale de Lausanne," RSB-IND-01-001 (Version 2. 0), http://rsb.epfl.ch/ files/content/sites/rsb2/files/Biofuels/Version\%202/Indicators/ 11-03-08\%20RSB\%20Indicators\%202-0.pdf, 2011.

[13] Global Bioenergy Partnership (GBEP), The Global Bioenergy Partnership Sustainability Indicators for Bioenergy, GBEP Secretariat, FAO, Environment, Climate Change and Bioenergy Division, Rome, Italy, 1st edition, 2011, http://www.arb.ca.gov/ fuels/lcfs/workgroups/lcfssustain/Report_21_December.pdf.

[14] Council on Sustainable Biomass Production (CSBP), Draft Provisional Standard For Sustainable Production of Agricultural Biomass, Council on Sustainable Biomass Production, 2011, http://www.csbp.org/.

[15] National Research Council (NRC), Monitoring Climate Change Impacts: Metrics at the Intersection of the Human and Earth Systems, The National Academies Press, Washington, DC, USA, 2008, http://www.nap.edu/catalog.php?record_id=12965.

[16] V. H. Dale and S. C. Beyeler, "Challenges in the development and use of ecological indicators," Ecological Indicators, vol. 1, no. 1, pp. 3-10, 2001.

[17] B. K. Sovacool and I. Mukherjee, "Conceptualizing and measuring energy security: a synthesized approach," Energy, vol. 36, no. 8, pp. 5343-5355, 2011.

[18] R. A. Efroymson, V. H. Dale, K. L. Kline et al., "Environmental indicators ofbiofuel sustainability: what about context?" Environmental Management. In press.

[19] J. Tassin, A. P. Missamba-Lola, and J. N. Marien, "Biodiversity of Eucalyptus plantations," Bois et Forêts des Tropiques, vol. 309, pp. 27-35, 2011.

[20] S. T. Berthrong, G. Pineiro, E. G. Jobbagy, and R. B. Jackson, "Soil C and N changes with afforestation of grasslands across gradients of precipitation and plantation age," Ecological Applications, vol. 22, pp. 76-86, 2012.

[21] C. Perez-Cruzado, P. Mansilla-Salinero, and R. RodriguezSoalleiro, "Influence of tree species on carbon sequestration in afforested pastures in a humid temperate region," Plant and Soil, vol. 353, pp. 333-353, 2012.

[22] D. I. Forrester, J. J. Collopy, C. L. Beadle, and T. G. Baker, "Interactive effects of simultaneously applied thinning, pruning and fertiliser application treatments on growth, biomass production and crown architecture in a young Eucalyptus nitens plantation," Forest Ecology and Management, vol. 267, pp. 104-116, 2012.

[23] M. Langholtz, D. R. Carter, D. L. Rockwood, and J. R. R. Alavalapati, "The influence of $\mathrm{CO} 2$ mitigation incentives on profitability of Eucalyptus production on clay settling areas in Florida," Biomass and Bioenergy, vol. 33, no. 5, pp. 785-792, 2009.

[24] M. Langholtz, D. R. Carter, D. L. Rockwood, and J. R. R. Alavalapati, "The economic feasibility of reclaiming phosphate mined lands with short-rotation woody crops in Florida," Journal of Forest Economics, vol. 12, no. 4, pp. 237-249, 2007.
[25] D. L. Rockwood, D. Carter, L. Ma, C. Tu, and G. R. Alker, Phytoremediation of Contaminated Sites Using Wood Biomass, Florida Center For Solid and Hazardous Waste Management, Gainesville, Fla, USA, 2001.

[26] D. L. Rockwood, C. Naidu, S. Segrest et al., "Short-rotation woody crops and phytoremediation: opportunities for agroforestry?" in Proceedings of the New Vistas in Agroforestry-A Compendium for the 1st World Congress of Agroforestry, pp. 51-63, Kluwer Academic, Dordrecht, The Netherlands, 2004.

[27] D. L. Rockwood, G. Peter, M. Langholtz, and B. Becker, "Genetically improved Eucalypts for novel applications and sites in Florida," in Proceedings of the Southern Forest Tree Improvement Conference, Raleigh, NC, USA, 2005.

[28] B. Tamang, D. L. Rockwood, M. Langholtz, E. Maehr, B. Becker, and S. Segrest, "Vegetation and soil quality changes associated with reclaiming phosphate-mine clay settling areas with fast growing trees," in Proceedings of the 32nd Annual Conference on Ecosystem Restoration and Creation, Tampa, Fla, USA, 2005.

[29] S. Wullschleger, S. Segrest, D. L. Rockwood, and C. Garten Jr, "Enhancing soil carbon sequestration on phosphate mine lands in Florida by planting short-rotation bioenergy crops," in Proceedings of the 3rd Annual Conference on Carbon Capture and Sequestration, Washington, DC, USA, 2004.

[30] R. J. Harper, S. J. Sochacki, K. R. J. Smettem, and N. Robinson, "Bioenergy feedstock potential from short-rotation woody crops in a dryland environment," Energy and Fuels, vol. 24, no. 1, pp. 225-231, 2010.

[31] C. W. Hedman, S. L. Grace, and S. E. King, "Vegetation composition and structure of southern coastal plain pine forests: an ecological comparison," Forest Ecology and Management, vol. 134, no. 1-3, pp. 233-247, 2000.

[32] M. Leslie, G. K. Meffe, J. L. Hardesty, and D. L. Adams, Conserving Biodiversity on Military Lands: A Handbook for Natural Resource Managers, The Nature Conservancy, Virginia, Va, USA, 1996.

[33] United States Government, The Energy Independence and Security Act of 2007 (H.R. 6), 2007.

[34] D. R. Gordon, K. J. Tancig, D. A. Onderdonk, and C. A. Gantz, "Assessing the invasive potential of biofuel species proposed for Florida and the United States using the Australian Weed Risk Assessment," Biomass and Bioenergy, vol. 35, no. 1, pp. 74-79, 2011.

[35] H. Trevor Booth, "Eucalypts and Their Potential for Invasiveness Particularly in Frost-Prone Regions," International Journal of Forestry Research, vol. 2012, Article ID 837165, 7 pages, 2012.

[36] B. Wicke, E. Smeets, V. Dornburg et al., "The global technical and economic potential of bioenergy from salt-affected soils," The Royal Society of Chemistry, vol. 4, pp. 2669-2681, 2011.

[37] D. Zhang and M. Polyakov, "The geographical distribution of plantation forests and land resources potentially available for pine plantations in the U.S. South," Biomass and Bioenergy, vol. 34, no. 12, pp. 1643-1654, 2010.

[38] D. Jenbere, M. Lemenih, and H. Kassa, "Expansion of eucalypt farm forestry and its determinants in Arsi Negelle District, South Central Ethiopia," Small-Scale Forestry, vol. 11, pp. 389-405, 2012.

[39] R. Gonzalez, T. Treasure, J. Wright et al., "Exploring the potential of Eucalyptus for energy production in the Southern United States: financial analysis of delivered biomass. Part I," Biomass and Bioenergy, vol. 35, no. 2, pp. 755-766, 2011.

[40] D. G. Hodges, A. J. Hartsell, C. Brandeis, T. J. Brandeis, and J. W. Bentley, "Recession effects on the forest and forest products 
industries of the South," Forest Products Journal, vol. 61, pp. 614-624, 2011.

[41] C. W. Woodall, C. E. Keegan, C. B. Sorenson et al., "An overview of the forest products sector downturn in the United States," Forest Products Journal, vol. 61, pp. 595-603, 2011.

[42] V. H. Dale, K. L. Kline, L. L. Wright, R. D. Perlack, M. Downing, and R. L. Graham, "Interactions among bioenergy feedstock choices, landscape dynamics, and land use," Ecological Applications, vol. 21, no. 4, pp. 1039-1054, 2011.

[43] S. Gonzalez-Garcia, M. T. Moreira, G. Feijoo, and R. J. Murphy, "Comparative life cycle assessment of ethanol production from fast-growing wood crops (black locust, Eucalyptus and poplar)," Biomass \& Bioenergy, vol. 39, pp. 378-388, 2012.

[44] R. Gonzalez, T. Treasure, R. Phillips et al., "Converting Eucalyptus biomass into ethanol: Financial and sensitivity analysis in a co-current dilute acid process. Part II," Biomass and Bioenergy, vol. 35, no. 2, pp. 767-772, 2011.

[45] A. Romani, G. Garrote, and J. C. Parajo, "Bioethanol production from autohydrolyzed Eucalyptus globulus by Simultaneous Saccharification and Fermentation operating at high solids loading," Fuel, vol. 94, pp. 305-312, 2012. 

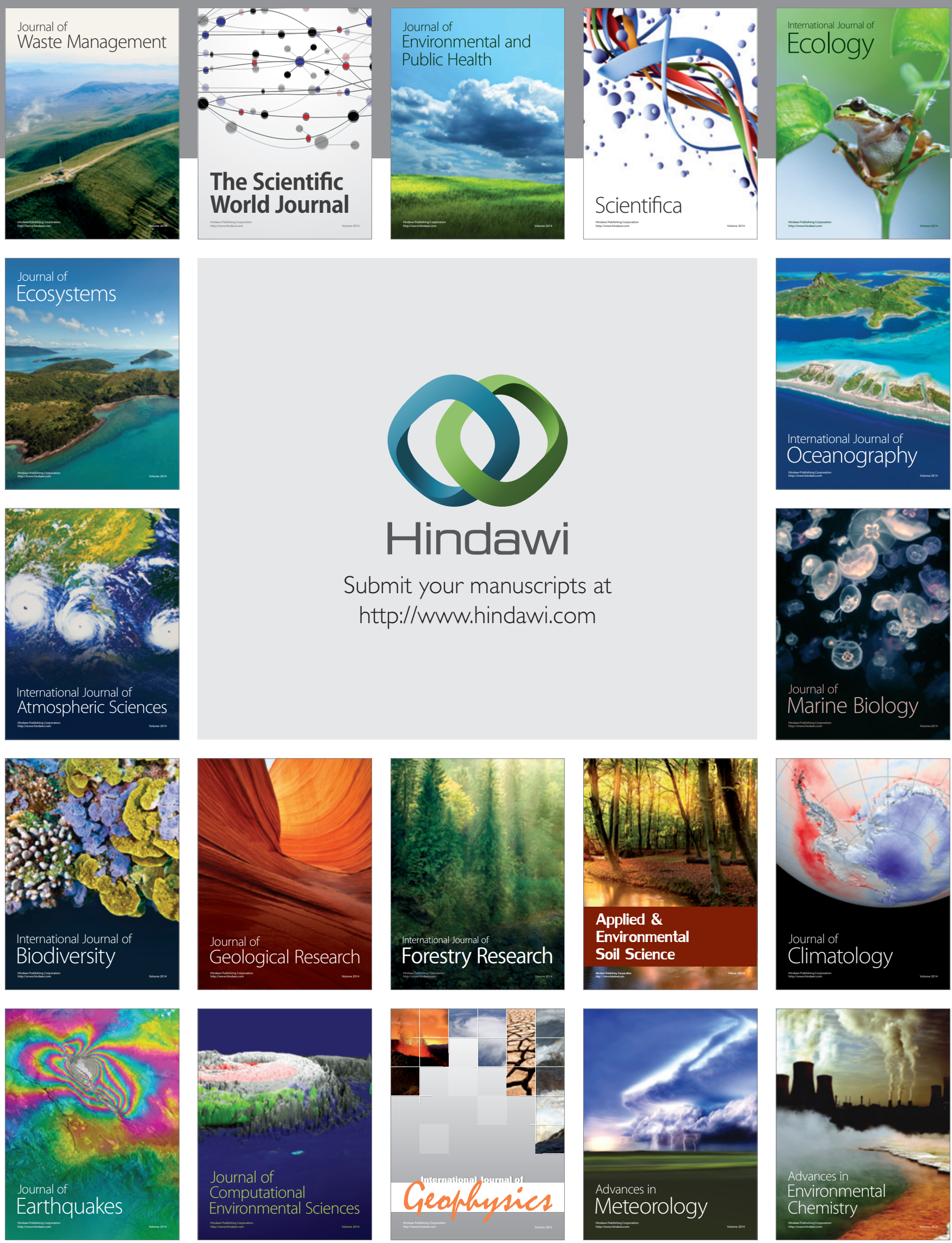